\title{
Documentation in labour among midwives in Madonna university teaching hospital elele, rivers state, Nigeria
}

\author{
Frank Maureen Dike ${ }^{1 *}$, Olayinka A. Onasoga ${ }^{2}$, Esther Njoku ${ }^{3}$
}

\author{
${ }^{1}$ Department of Nursing, Niger Delta University, Wilberforce Island, Bayelsa State, Nigeria \\ ${ }^{2}$ Department of Nursing, College of Health Sciences, University of Ilorin, Ilorin \\ ${ }^{3}$ Department of Nursing, Madonna University, Elele, Rivers State, Nigeria
}

Received: 29 August 2015

Revised: 07 September 2015

Accepted: 09 September 2015

\author{
*Correspondence: \\ Dr. Frank Maureen Dike, \\ E-mail: maureendikefrank@yahoo.co.uk
}

Copyright: (C) the author(s), publisher and licensee Medip Academy. This is an open-access article distributed under the terms of the Creative Commons Attribution Non-Commercial License, which permits unrestricted non-commercial use, distribution, and reproduction in any medium, provided the original work is properly cited.

\begin{abstract}
Background: Documentation is a fundamental and vital communication tool among healthcare professionals. It is an essential part of midwifery that has clinical and legal implications for the client and midwife as well as the health care institution. This study assessed the knowledge, practice of and factors influencing documentation in labour among nurses in Madonna University Teaching Hospital, Elele Rivers State.

Methods: This is a descriptive cross sectional study with a sample size of 102 nurses selected using purposive sampling technique. The instrument for data collection was structured questionnaire. Data collected were analysed using simple percentage and frequency table.

Results: The findings of the study showed that midwives had good knowledge of documentation in labour, but their practices were poor. Factors influencing documentation includes; time, the attitude of the midwives (terming documentation to be unnecessary), and few number of midwives working in a shift.

Conclusions: It was recommended that, the consequences of not documenting in labour should be emphasized and penalty is given to midwives who do not document properly. More staff should be assigned to client and the shift adjusted to shorter hours to prevent fatigue and tediousness.
\end{abstract}

Keywords: Documentation, Midwives, Knowledge, Practice

\section{INTRODUCTION}

Labour is much more than a purely physical event by which the fetus, placenta and membranes are expelled through the birth canal. What happens during labour can affect the relationship between mother and baby and can influence the likelihood of future pregnancies. ${ }^{1}$

Midwifery documentation refers to any and all forms of records done by a midwife in a professional capacity in relation to the provision of midwifery care.
Documentation in labour is referred to as the written or electronically generated information about a client in labour, describing the care of services provided to that client. It is an accurate account of events that have occurred and when they occurred, such as; the onset of labour, fetal heart rate, the time of the rupture of membrane, the characteristics of the membranes, presentation and lie of the fetus among others. ${ }^{2}$

Documentation in labour includes written and electronic health records, audio and video tapes, email, facsimiles, images (photograph and diagrams), observation charts, 
check list, communication books, shift/management reports, incidents report or any other type or form of records pertaining to health care. It may be clinical data, management or educational information or research analysis; it may also include anecdotal notes or personal reflections by the midwife. ${ }^{3}$

All of these records describe the care delivered to, and received by the patient and as such can be used as evidence in any investigation into the care of the patient. Should legal proceedings arise as a result of an investigation, all or any of these can also be called as evidence in a court of law with the individual healthcare practitioner being required to defend their decision making and interventions in relation to any patient care provided.

Good record keeping is an integral part of practice and essential to the provision of safe and effective care. It is especially sensitive and critical because the midwife is caring for two persons together whose best interest may be in conflict. When patient's circumstances indicate the need for more frequent assessments and documentation, assess as frequently as needed to ensure the best possible outcome of labour and delivery. ${ }^{4}$

It has a range of important functions including; improving communication between healthcare professionals, supporting delivery and continuity of patient care, demonstrating clinical judgments and decision making and identifying risk for patients

Hence, thorough documentation in labour help midwives communicate to other healthcare professionals their observations, decisions, actions and outcomes of care which is critical to proper treatment and management. ${ }^{5}$

Midwifery documentation in labour is an important tool for evaluating the care provided by the midwives and it emphasizes monitoring quality of health care based on the patients' outcome. ${ }^{6,7}$ Midwifery documents can be used for ensuring quality of care of woman in labour through communication, furnishing, legal evidence of the process and outcomes of labour, evaluation of the quality, efficiency and effectiveness of the client care, providing data for research, financial and ethical quality assurance purposes. It can also be used to provide the infrastructure that will support the development of midwifery knowledge, assisting in establishment of benchmark for the development of midwifery education and standards of clinical practice, ensuring the appropriate reimbursement, providing the data for future health care planning, providing data for other purposes such as risk management, learning experience for students and protection of clients rights.

Documentation in health care records must be clear and accurate, legible and in English (or any other language common among the health care providers or approved by the health care institutions where care is being given), use approved abbreviations and symbols, written in dark ink that is readily reproducible, legible, and difficult to erase. $^{8}$

Midwives must ensure clear, concise, accurate, complete, objective, legible and timely documentation to fulfil both clinical and legal imperatives2. Nurse-midwives must keep clear, accurate and timely records of care they provide to their patients to support communication, continuity and decision making. This includes all forms of patient records, such as anything that is documented about a patient and her care and treatment. ${ }^{9}$

However if the midwives has not met standards in writing good documentations in labour, this can result in harm to the client because important information regarding treatment and valuable observations can be overlooked. Poor documentation may be used negatively by clients' attorney in lawsuits. ${ }^{10}$

Despite the obvious benefit of high quality documentations in labour, midwifery records are often incomplete, inappropriate and irregular, and that mostly, midwifery records do not describe the clients' problems and conditions. ${ }^{11}$ Midwifery care, interventions, and outcomes are not consistently written and midwifery documents often show legal inaccuracies.

Despite these advantages it has being observed that most midwives are reluctant and as such do not document incidents of labour, those who do often do that in a nonchalant attitude probably due to lack of time or knowledge of what to document and the implication of not documenting.

\section{METHODS}

A descriptive design was used for this study and the study was conducted in Madonna University Teaching Hospital (MUTH) Elele in Ikwere Local Government Area of Rivers State Nigeria. MUTH has a working capacity of 500 staff comprising of Doctors, Nurse-midwives, Physiotherapists, Radiologist and non-medical staff. The hospital is made up of sub-units such as medical wards, surgical wards, paediatric unit outpatient department, accident and emergency (casualty), theatre, obstetrics and gynaecology units and psychiatric unit. A purposive sampling technique was used to select a sample size of 102 nurse midwives which is the entire population of nurse-midwives working in the hospital at the time of the study. Relevant data was collected through the use of structured questionnaire among the population under study. The structured questionnaire was in four sections, (sections A, B, C and D) section A has 4 items to elicit information of the respondent's socio-demographic data, section B has13 items to elicit information of the respondent's knowledge on documentation, section $\mathrm{C}$ has 5 items eliciting the practice of documentation in labor and section $\mathrm{D}$ has 5 items on factors influencing documentation. 
A correct option was scored 1 while incorrect response was scored zero. A score of $60 \%$ and above was judged good knowledge; practiced and motivating factors while $<60 \%$ was judged poor knowledge, poor practice and hindering factors.

Two (2) specialists in measurement and evaluation assessed the face and content validity of instrument and their comments were used to make necessary corrections before administering them to the respondents.

Reliability of the study was ascertained by using test retest method, 10 copies of the questionnaire were distributed to 10 nurse midwives of University Teaching Hospital Port Harcourt, and one week later the same but fresh copies of the questionnaire were given to the same group of people. The first and second results were analysing using Spearman Rank Correlation Co-efficient which yielded a correlation coefficient of 0.73 . This is considered adequate for the study.

Informed verbal consent was obtained from the respondents after explaining the purpose of the study to them. They were also assured that any information provided will be treated confidentially and not used against them in any way.

The data collected was analysed using descriptive statistics in statistical package for social sciences (SPSS) version 19.0.

\section{RESULTS}

Out of the 102 questionnaires distributed to the respondents, only 92 questionnaires were void of error and same number were analysed.

Six (6) of the questionnaires were not returned, four (4) were incompletely and improperly filled.

Table 1 reveals that majority $43(46.7 \%)$ of the respondents were within the age range of 20-30 years, followed by 41 years and above 27 (29.4\%) and the remaining 31-40 years constituted 22 (23.9\%). Majority $88(95.7 \%)$ of the respondents were females while $4(4.3)$ were males. More than half $52(56.6 \%)$ were registered nurse-midwives (RNM), while $30 \quad(32.6 \%)$ were midwives (RM) with other diploma in nursing and only $20(12.6 \%)$. constituted midwives (RNM) with degree in nursing. Considering their rank, majority of the midwives $35(38 \%)$ were No $1,25(27.2 \%)$ each were No 2 and SNO, $6(6.5 \%)$ were ACNO and only 1 (1.1\%) CNO.

Table 2 above shows that majority $80(87 \%)$ of the respondents knew what documentation means. With regards to purpose of documentation in labour, all the respondents $92(100 \%)$ said that documentation is necessary in labour in order to promote continuity of care, $82(89.1 \%)$ said is essential for legal backing, 80 $(87.0 \%)$ said is important in providing quality care, while
$78(84.8 \%)$ and $60(65.0 \%)$ opined that it is used for research and health planning purposes respectively. All the respondents $92(100 \%)$ stated that fetal heart rate, dilation of the cervix date and time of the onset of labour and frequency of uterine contraction were important things to document during labour.

Table 3 shows that majority $71(77.2 \%)$ of the respondents did not document immediately after observation while very few 21 (22.8\%) did. Majority 73 $(79 \%)$ of the respondents said that they document their findings only when it is convenient while $19(21 \%)$ said no. More than half 60 (65) claimed that they document only for primips and complicated cases. Only few 35 $(38 \%)$ asserted that they use standard charts (parthograph) during labour for documentation.

Table 4 showed that majority of the respondents 72 $(78.3 \%)$ said that lack of time influences documentation while $20(21.7 \%)$ said that it does not. $54(58.7 \%)$ responded positively that attending to too many patients is a hindering factor while $38(41 \%)$ responded negatively. Only $4(4.3 \%)$ said that no documenting materials influences documentation while majority $88(95.7 \%)$ said it does not. 48 (52.2) did not view documentation especially in normal cases as being necessary while $48(52.2 \%)$ believe that it is necessary. Majority $68(79.1 \%)$ responded positively that few staff on duty influences documentation while 24 (20.9\%) responded negatively.

Table 1: Frequency distribution of respondents' demographic data.

\begin{tabular}{|lll|}
\hline Age & $\begin{array}{l}\text { Frequency } \\
(\mathbf{n = 9 2})\end{array}$ & $\begin{array}{l}\text { Percentage } \\
(\%)\end{array}$ \\
\hline $20-30$ & 43 & 46.7 \\
$31-40$ & 22 & 23.9 \\
41 and above & 27 & 29.4 \\
\hline Gender & & \\
Female & 88 & 95.7 \\
Male & 4 & 4.3 \\
\hline Qualification & & \\
RM with other & 30 & 32.6 \\
diploma in nursing & 52 & 56.6 \\
RNM (only) & 20 & 21.7 \\
BNSC,RM,RNM & & \\
\hline Rank & & 27.2 \\
NO11 & 25 & 38.0 \\
NO1 & 35 & 27.2 \\
SNO & 25 & 6.5 \\
ACNO & 6 & 1.1 \\
CNO & 1 & 100 \\
Total & 92 & \\
\hline
\end{tabular}




\section{DISCUSSION}

\section{Socio demographic data of the respondents}

The socio demographic data showed that about half of the respondents $43(46.7 \%)$ were within the age range of 20 30 years, and were females $88(95.7 \%)$. All the respondents have a minimum of double qualifications. Majority of the midwives were junior cadre and there was gross shortage of senior cadre of midwives (SNO, ACNO and CNO). This may influence the practice of documentation which will consequently affect the quality of care and services by the few staff.

Increased workload and decreased number of staff, hinders midwives from documenting detailed information on a client in labour, since they are often faced with challenges of completing workload within the shift rather than documenting two hours of vital sign checked on a laboring woman. ${ }^{12}$ Long shifts, intense workload and current economic rationalization (leading to suboptimal staffing levels) can lead to a culture where poor documentation becomes common. ${ }^{13}$

\section{Knowledge of documentation}

The study showed that majority $80(87 \%)$ of the respondents knew what documentation means and all the respondents $92(100 \%)$ said that documentation is necessary to promote continuity of care, $82(89.1 \%)$ said is essential for legal backing, $80(87.0 \%)$ said is important in providing quality care, while $78(84.8 \%)$ and $60(65.0 \%)$ opined that it is used for research and health planning purposes respectively. This implies that most of the midwives have good knowledge of documentation 80 $(87 \%)$, its purposes $82(89.1 \%)$, and what should be documented $82(89.1 \%)$ in labour. This is in line with other findings, which observed that many midwives have good knowledge about documentation and its importance in labour 13.

Table 2: Knowledge of midwives on documentation.

\begin{tabular}{|c|c|c|c|c|}
\hline \multirow[b]{2}{*}{ Items } & \multirow[b]{2}{*}{$\begin{array}{l}\text { Correct } \\
\text { Answer }\end{array}$} & \multicolumn{2}{|l|}{ Responses } & \multirow[b]{2}{*}{ Remark } \\
\hline & & $\begin{array}{l}\text { Yes } \\
\text { F }(\%)\end{array}$ & $\begin{array}{l}\mathrm{NO} \\
\mathrm{F}(\%)\end{array}$ & \\
\hline $\begin{array}{l}\text { Documentation means writing information or proof of } \\
\text { what has been done }\end{array}$ & Yes & $80(87)$ & $12(13.0)$ & Good knowledge \\
\hline \multicolumn{5}{|l|}{ Purpose of documentation in labour } \\
\hline Legal purpose & Yes & $82(89.1)$ & $10(10.9)$ & Good knowledge \\
\hline Promotion of continuity of care & Yes & $92(100.0)$ & $0(0.0)$ & Good knowledge \\
\hline providing quality care & Yes & $80(87.0)$ & $12(13.0)$ & Good knowledge \\
\hline Developing midwifery education & Yes & $35(38.0)$ & $57(62.0)$ & Poor knowledge \\
\hline Health planning & Yes & $60(65.0)$ & $32(35)$ & Good knowledge \\
\hline Research & Yes & $78(84.8)$ & $14(15.2)$ & Good knowledge \\
\hline \multicolumn{5}{|l|}{ Important things to document during labour } \\
\hline Fetal status and station & Yes & $92(100)$ & $0(0.0)$ & Good knowledge \\
\hline Cervical Dilation & Yes & $92(100)$ & $0(0.0)$ & Good knowledge \\
\hline Cervical effacement & Yes & $82(89.1)$ & $10(10.1)$ & Good knowledge \\
\hline Date and time of the onset of labour & Yes & $92(100)$ & $0(0.0)$ & Good knowledge \\
\hline Level of shouting and/or screaming & No & $37(40.2)$ & $55(59.8)$ & Good knowledge \\
\hline uterine activity & Yes & $92(100)$ & $0(0.0)$ & Good knowledge \\
\hline Status of membrane & Yes & $80(87)$ & $12(13.0)$ & Good knowledge \\
\hline
\end{tabular}

\section{Practice of documentation}

The study also showed that majority 71 (77.2\%) of the respondents did not document immediately following a procedure and only document when it is convenient. Only few $35(38 \%)$ asserted that they use standard charts (parthograph) during labour for documentation. Available reports indicated that good quality documentation is an essential part of midwifery practice and is linked with improvements in patient care. ${ }^{13,15}$ Yet majority of the respondents showed poor practice of documentation during labour despite their adequate knowledge. This does not support other findings that midwives' ability to create documentation depends on their knowledge on importance of documentation and what to document. ${ }^{16}$

\section{Factors influencing documentation}

Table 4 showed that lack of time 72 (78.3\%), too many workload $54(58.7 \%)$ and few staff $68(79.1 \%)$ have hindering influences on documentation. This observation was supported by the findings of other studies: Often time midwives may find it difficult documenting incidence of labour not necessarily due to lack of 
knowledge but time and workload, some midwives complained of too many clients hindering them from practicing effective documentation. ${ }^{17}$

Midwives often do not have the time documenting detailed information on clients in labour due to increased workload and decreased number of staff and that they are often faced with the challenges of completing workload within the shift rather than documenting two (2) hours of observations made on a laboring woman. ${ }^{12}$

This study also observed that a good number of the respondents $44(47.8 \%)$ terms it unnecessary documenting in labour. Time spent documenting labour is generally not regarded by midwives as being part of client's care even though there is a nursing intervention classification (NIC) term for it (partograph), also some midwives term it unnecessary documenting findings which seems abnormal, but observed that there were incidents where only normal findings were documented. ${ }^{13,16}$

\section{Summary}

The study was carried out to determine knowledge and practice of documentation among midwives in Madonna University Teaching Hospital, Rivers State. The total population was used; instrument used for data collection was structured questionnaire. Validity and reliability of the instrument were ensured. The research design adopted was a descriptive survey. The target population consisted of all nurse midwives working in Madonna University Teaching Hospital Elele Rivers State. 102 copies of questionnaire were distributed and 92 copies were retrieved giving a $90 \%$ return rate. The data collected were analysed and the findings discussed.

Table 3: Practice of documentation.

\begin{tabular}{|llll|}
\hline \multicolumn{3}{l}{ Responses } & \\
\hline & $\begin{array}{l}\text { Yes } \\
\text { F }(\%)\end{array}$ & $\begin{array}{r}\text { No } \\
\text { F (\%) }\end{array}$ & Remark \\
\hline $\begin{array}{l}\text { I document } \\
\text { Immediately after } \\
\text { each observation }\end{array}$ & $21(22.8)$ & $71(77.2)$ & $\begin{array}{l}\text { Poor } \\
\text { practice }\end{array}$ \\
\hline $\begin{array}{l}\text { I document only } \\
\text { when convenient }\end{array}$ & $73(79)$ & $19(21)$ & $\begin{array}{l}\text { Poor } \\
\text { practice }\end{array}$ \\
\hline $\begin{array}{l}\text { I document only for } \\
\text { primips and } \\
\text { complicated cases }\end{array}$ & $60(65)$ & $32(35)$ & $\begin{array}{l}\text { Poor } \\
\text { practice }\end{array}$ \\
\hline $\begin{array}{l}\text { I like documenting } \\
\text { only when the labour } \\
\text { is normal }\end{array}$ & $3(3)$ & $89(97)$ & $\begin{array}{l}\text { Good } \\
\text { practice }\end{array}$ \\
\hline $\begin{array}{l}\text { I document using the } \\
\text { standard } \\
\text { charts(parthograph) }\end{array}$ & $35(38)$ & $57(62)$ & $\begin{array}{l}\text { Poor } \\
\text { practice }\end{array}$ \\
\hline
\end{tabular}

\section{Implication to midwifery}

This study helps the nurse on the following ways;

1. To encourage the practice of documentation in labour among midwives in Madonna University Teaching Hospital Elele, Rivers State.

2. To determine factors influencing the practice of documentation among midwives.

Table 4: Factors influencing the Practice of documentation.

\begin{tabular}{|llll|}
\hline \multicolumn{4}{l}{ Responses } \\
& $\begin{array}{l}\text { Yes } \\
\mathrm{F}(\%)\end{array}$ & $\begin{array}{c}\text { No } \\
\mathrm{F}(\%)\end{array}$ & Remark \\
\hline $\begin{array}{l}\text { Lack of sufficient } \\
\text { time }\end{array}$ & $72(78.3)$ & $20(21.7)$ & $\begin{array}{l}\text { Hindering } \\
\text { factor }\end{array}$ \\
\hline $\begin{array}{l}\text { Too many clients to } \\
\text { attend to }\end{array}$ & $54(58.7)$ & $38(41.3)$ & $\begin{array}{l}\text { Hindering } \\
\text { factor }\end{array}$ \\
\hline $\begin{array}{l}\text { No documentation } \\
\text { materials }\end{array}$ & $4(4.3)$ & $88(95.7)$ & $\begin{array}{l}\text { Motivatin } \\
\text { g f actor }\end{array}$ \\
\hline $\begin{array}{l}\text { Not necessary } \\
\text { especially in normal } \\
\text { cases }\end{array}$ & $44(47.8)$ & $48(52.2)$ & $\begin{array}{l}\text { Hindering } \\
\text { factor }\end{array}$ \\
\hline Few staff on duty & $68(79.1)$ & $24(20.9)$ & $\begin{array}{l}\text { Hindering } \\
\text { factor }\end{array}$ \\
\hline
\end{tabular}

\section{CONCLUSIONS}

Medical document serves many purposes; First and foremost, they document the history of examination, diagnosis and treatment of a patient. This information is vital for all providers involved in a patient's care and for any subsequent new provider who assumes responsibility for the patient. In disciplinary or peer review matters, medical documents can justify (or refute) the need for a particular treatment. In reimbursement and utilization disputes, medical records can document what services were rendered and whether they were medically necessary. Medical records are the single most important evidence for the provider whenever a malpractice claim, or other inquiry, arises concerning patient care. In today's health care environment, which now features multispecialty care, in ever changing health care networks, and often requires consumers to transfer to different providers, the need for comprehensive, accurate medical records simply cannot be overemphasized.

This study was undertaken to determine the knowledge, practice of and factors influencing documentation among midwives in Madonna university teaching hospital, Rivers State.

Based on the analysis and discussions of the findings, the researcher came out with the following conclusion;

1. Midwives have good knowledge of documentation; they know what should be documented and also the importance of documentation. 
2. There is poor practice of documentation among the respondents.

3. Various factors hinder the practice of documentation

\section{Recommendation}

Based on the findings of this study, the following recommendations were made:

1. Midwifery education: The Nursing and Midwifery Council should include documentation skills in the curriculum of Midwifery training and establish policies to help conduct programs on documentation for every midwife.

2. The consequences of not documenting in labour should be emphasized and penalty be given to midwives who do not document properly.

More staffs should be assigned to client and the shift adjusted to 8 hours to prevent fatigue and tediousness.

\section{Funding: No funding sources}

Conflict of interest: None declared

Ethical approval: The study was approved by the Institutional Ethics Committee

\section{REFERENCES}

1. Diane.GD. Enrolment and graduations in baccalavreate and graduate programs in nursing, washington, DC. American Association of colleges of nursing, 2005.

2. Registered nursing and Midwifery Association of Britsh Columbia. Effective practice of documentation. British Journal of Public Health. 2013;11(1):32-3.

3. Samson V. Fundamentals of documentation, Ibadan: Karaft books Ltd, 2005.

4. Anderson DA. Educational research basic issues and methodology; Ibadan; wisdom publisher Limited, 2010.

5. Nursing Council of Hong Kong Guide to Good Nursing Practice Nursing Documentation Developed by the Professional Development Committee of the Nursing Council of Hong Kong, 2010.
6. Collins O. Barriers to Health Care Access among Midwives. American journal of Public Health. 2010;35(4),602-3.

7. Willis PT. Documentation in midwifery practice, Midwife's Journal, continuity of care. 2005;2(5):16.

8. Shokoyemi JD. Knowledge and practice of documentation, England: Hopkins publishers, 2012.

9. Royal college of nursing. (2015). https//enwikipedia.org/wiki/Royal_College_of_Nursi ng.

10. Brian D. Understanding Behavior, New York: hollrinehari and Winston publisher, 2007.

11. Albert SW. Fundamentals of nursing; concepts, process and practice $8^{\text {th }}$ edition New jersey: Pearson prentice, 2010.

12. Alkhan RQ. Women's health services and gyneacology. Wakened physician practice, Raleigh, NC, 2011.

13. Ahmed AK. Principles and Practice of Community Health in Africa, Ibadan: university press, 2006.

14. Philip F. Nursing research textbook; principle and method. 2012:62. retrieved on 14/3/2013 from www, books.google.com.nig.

15. Puissant S. Factors facilitating and inhibiting research, 2010. Retrieved from www.pub med central Nih.gone/aritc leveder.com and http;www.biomed central.

16. Association for Women's Health, Obstetric and Neonatal Nurses (2009). Tropical medicine and public health. 2009;1(1):1-10.

17. Agwung BB. The periodic health examination.medline splus Goldman's cecil medicine $24^{\text {th }}$ edition Philadelphia,pa; saunder Elsevier, 2010.

18. Baron DF, Bryan M. Nursing research principles and methods. $7^{\text {th }}$ edition. Lippincott Williams and Wilkins, 2008.

Cite this article as: Dike FM, Onasoga OA, Njoku E. Documentation in labour among midwives in Madonna university teaching hospital elele, rivers state, Nigeria. Int J Reprod Contracept Obstet Gynecol 2015;4:1404-9. 